\title{
Economic Reforms in the Sovereign States of the Former Soviet Union
}

"Unchanging work at a uniform task kills the explosive flow of a man's animal spirits,
which draw refreshing zest from a simple change of activity."

-Karl Marx

THE REFRESHING ZEST of recent days apparently would not have surprised Karl Marx, ${ }^{1}$ although presumably he would have been amazed at the changes in the former Soviet Union and the assertiveness of its constituent states following August's failed coup and the collapse of the Communist party. He would not be alone, as policymakers and analysts everywhere adjust to the transformed political and economic landscape, in which the former republics dominate. Even Grigory Yavlinsky, the talented and most ubiquitous all-union reformer, has concluded that there "is no place for reform on an all-union level." 2 Certainly part of the aftermath of the failed coup will be a wider acceptance of the necessity of recognizing and accommodating parallel economic reform efforts in the sovereign states that will now emerge.

This change of focus has not been fully welcomed by all in the West. At a political level, President George Bush finds it easier to contemplate dealing with a single entity headed by a familiar Mikhail Gorbachev than to think about dealing with some unknown number of unfamiliar states. On the economic plane, many of those Western analysts who were not completely overwhelmed by the complexity of the required changes in the Soviet economy used to take comfort in the hope that there could be

I am grateful for the help of James Cashel, Santiago Eder, Christopher Kedzie, and Frank Lindsay.

1. Marx as quoted in Andrews (1990, p. 289).

2. Frances X. Clines, "A Bleak Economy Dims Soviet Hopes for a Free Market," New York Times, September 9, 1991, p. A1. 
a single macroeconomic policy, currency, and legal framework. ${ }^{3}$ But this hope for a centrally planned reform has never been embraced outside Moscow, and the new centers of power will be loathe to cede much back to the old center. ${ }^{4}$ Those interested in assisting in economic reform must address this new reality.

My purpose here is to highlight some of the arguments behind and implications of the necessary evolution of multilateral economic reform efforts, motivated and illustrated by the case of Ukraine. The precise nature of the future economic confederation in the former Soviet Union is far from clear. Anything is possible, from a relatively centralized, although smaller, transformed union to a looser confederation that includes the Baltics and nearly all of Eastern Europe. However, it is clear that the demands for greater autonomy in economic policy cannot be met with yet another reform plan that presumes a strong controlling center.

\section{Problems in Soviet Economic Reform}

Most of the well-recognized problems of formerly planned economies are visiting themselves on the component entities of the old Soviet Union. Indeed, compared with the Eastern European countries of Czechoslovakia, Hungary, and Poland, not to mention East Germany, the problems in the Soviet Union are acknowledged to be far more difficult. The memory of political independence and a market economy is far dimmer in the latter, and the wreckage of central planning is at least as pervasive. As Anders Åslund remarked, "The Soviet economic system has been counted out many times before, but never has it appeared so devoid of advantages." 5

Predictions of a Soviet fiscal crisis have been borne out by events. ${ }^{6}$

3. For a summary of the main elements of conventional Western proposals for economic reform, with a discussion of the relevance of these recommendations for the new sovereign states, see Nordhaus, Peck, and Richardson in this volume.

4. "But years of suppressed anger over nationality issues, combined with the natural instinct of each republic and city to protect itself against the chaos of the system as a whole, may give such force to separatism that there remains little support for even a loose economic union." Hewett (1990, p. 167).

5. Åslund (1989, p. 21).

6. Shelton (1989); Åslund (1991). 
Current estimates have the 1991 central budget deficit approaching 20 percent of gross national product; official prices have already more than doubled this year, and there are many reports of imminent hyperinflation. ${ }^{7}$ Of course, the effect of official inflation is confounded in a system with such extensive grey and black markets. However, even prices in these markets have been on the rise, with a recent sale of dollars attracting a bid of 75 rubles per dollar in a currency auction in Tallinn, Estonia, in July $1991 .{ }^{8}$ Rapid depreciation of the ruble worries common citizens and foreign investors and reinforces the appearance and reality of economic collapse.

The old economic system was organized like a wheel, with the hub in Moscow and communications along the spokes. Despite the skill of Soviet managers, who work around the constraints of the system, ${ }^{9}$ there is an astonishing lack of information at the enterprise level about suppliers or customers. Without this information, the enterprises are floundering and production is falling. Control by the central ministries has withered and no organized system has been created to take their place. As a result, Gosplan and others have been warning of a fall in output in the state sector in 1991 that will rival the Great Depression in the United States. ${ }^{10}$ As the new leaders turn from their political miracle to face their economic misfortune, they must surely agree with Oscar Wilde: "When the gods wish to punish us they answer our prayers." 11

Everyone in the old Soviet Union recognizes the urgent need for economic reform in the direction of freer markets, but there is no agreement on the steps needed to make that move. The problem runs far deeper than just a lack of familiarity with markets and capitalism. The leadership and the population are steeped in a communist ideology and the val-

7. Clines, “A Bleak Economy,”'p. A8.

8. United Press International, "Dollar Fetches 75 Rubles at Estonia Auction," July 10, 1991.

9. Hewett (1988, p. 160).

10. "You have to grasp the enormousness of the impending Soviet economic failure. In the Great Depression, U.S. gross national product (the nation's output) dropped 30 percent between 1929 and 1933. It didn't regain its 1929 level until 1939. Unemployment averaged 18 percent for the decade. The Soviet Union is now approaching a comparable calamity. In the first half of 1991, its GNP declined about 10 percent. 'By the end of 1991, it's going to fall 20 percent,' Soviet economist Vladimir Popov recently told Barron's magazine.' See Robert J. Samuelson, “The Coming Soviet Slump,' Washington Post, September 4, 1991, p. A19.

11. As quoted in Stevenson (1967, p. 14). 
ues that accompany it. The death of the Communist party does not guarantee full burial of its ideals. For instance, notwithstanding the fact that the distribution of income in the Soviet Union already reflects disparities far from the communist ideal, ${ }^{12}$ every reform initiative faces criticism if in the end it favors some citizens over others, such as those who work over those who do not. Former Prime Minister Valentin Pavlov's April 1991 "reform" of raising prices, and then wages to compensate for 85 percent of the price increase, ${ }^{13}$ was seen in many quarters as necessary, or at least understandable. Given the dire straits of the poorest citizens, whose monthly pensions recently averaged only about 55 rubles,,$^{14}$ an emphasis on "social protection" permeates evaluations of every specific proposal for revamping the economy. The concern is laudable; the challenge will be to target social protection without distorting the entire economy. ${ }^{15}$

The values of communism and central planning will be hard to leave behind. In Ukraine, radical proposals for tax reform in October 1990 contained numerous "administrative" taxes applying to deviations from norms in wages, employment, and production, thereby restoring central planning through tax levies. More recently, reform legislation on foreign economic activity focused so heavily on an onerous division of the economic pie that there seemed little reason to hope that the pie would ever appear. There was no attention to tax holidays or other incentives to stimulate foreign economic activity. These relapses are all part of the same tale. Soviet economic statistics routinely exclude most useful services as unproductive; investment occurs without any provision to recover capital; and brokers ("speculators") are subject to arrest. To Western eyes these policies are anomalies and present serious handicaps for economic reform; to the average Soviet these conditions seem natural. Clearly, underlying Soviet values must be unlearned. This will be no easy task.

12. Bergson (1984, pp. 1052-99).

13. Pavlov announced the price increases with an 85 percent compensation in February, indicating that the increases would be implemented sometime before October 1991. See "Soviet Premier Reveals Consumer Pricing Plan; Compensation to Be Paid for Higher Costs," Washington Post, February 19, 1991, p. A6. In the event, official prices rose in April 1991, with one price index jumping 170 percent in that month; see Shleifer and Vishny in this volume (especially table 3 ).

14. In 1988, the average monthly pension on collective farms was 54.3 rubles. International Monetary Fund and others (1991, vol. 2, p. 211).

15. Williamson (1991, p. 82). 


\section{Interdependent Sovereign States}

The devolution of power to the individual sovereign states will complicate at least the theory of the economic transition. In addition to the task of developing individual economic reform plans, given little experience and a decades-long brain drain to Moscow,${ }^{16}$ the newly sovereign states must confront their pervasive interdependence. Years of central planning have bound these sovereign states together in ways that surpass normal conditions in market economies:

The Soviet economy embraces a substantial interregional division of labor, arising in part from varying comparative advantages and a common economic union. The division of labor is reinforced by two factors more peculiar to the Soviet economic system. The first is the organization of the economic ministries along branch lines, which often favors interrepublican trade within a ministry over intrarepublican trade across ministries. The second is the emphasis on economies of scale, which sometimes leaves only 1 or 2 enterprises supplying the entire union. ${ }^{17}$

As shown in figure 1, trade among the former republics reflects this high degree of specialization. The average percentage of interrepublican trade for the USSR is brought down by the relatively low trade ratio for Russia; all other republics are far more dependent on each other's trade, with interrepublican exports typically five to ten times exports abroad. ${ }^{18}$ Hence, contrary to an earlier assessment that "the Soviet Union has a real choice as to whether it accompanies reform . . . by opening up the economy," "19 the new sovereign states have no such option. The rush to create new bilateral agreements reflects their visceral understanding of their interdependence through trade,${ }^{20}$ which makes autarchy seemingly impossible, no matter what the political preference of the people.

Moreover, these new negotiations among sovereign states must proceed against a background of suspicion that the current system has ex-

16. For example, Grigory Yavlinsky has a Ukrainian heritage.

17. IMF and others (1991, vol. 1, p. 193).

18. IMF and others (1991, vol. 1, p. 225).

19. Williamson (1991, p. 80).

20. Ukraine and Russia signed a bilateral friendship treaty in November 1990, reinforced and expanded by a joint communique after the surprise visit to Kiev on August 28, 1991, by Russian Vice-President Alexander Rutskoi and Leningrad's mayor, Anatoly Sobchak. See Peter Maass, "Ukraine, Russia Agree to Inter-Republic Pact; Accord Omits Significant Role by Kremlin," Washington Post, August 29, 1991, p. A39. 
Figure 1. Soviet Exports as a Percent of Net Material Product, by Region, 1988 Percent

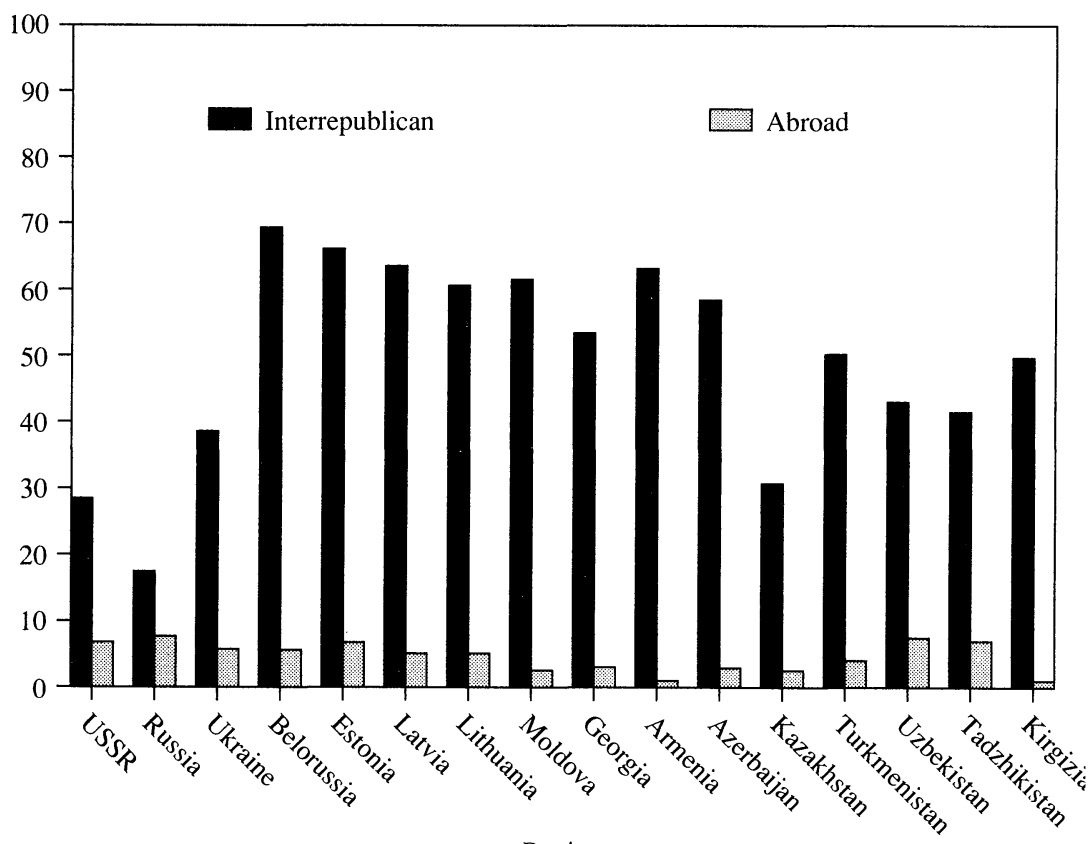

Region

Source: IMF and others (1991, vol. 2, p. 225).

ploited each former republic to the benefit of the others. Certainly current domestic prices are so distorted that it is no easy task to untangle the subsidies or to separate the resources that disappeared into the black hole of the central plan. ${ }^{21}$ It may be that everyone will be immediately better off as they assert their independence, but the best evidence does not support this contention. Unfortunately for the political road ahead, the biggest beneficiary of the new trade arrangements is likely to be Russia. According to estimates of interrepublican trade balances recalculated to world prices from current domestic prices, Russia, with its large supply of hugely underpriced oil, has the most to gain from arm's length trades. ${ }^{22}$ This fact will not sit well with the many new states that fear

21. This conclusion is based on 1988 data from IMF and others (1991, vol. 2, p. 14).

22. "Remaking the Soviet Union: Beyond Aid," The Economist, July 13, 1991, p. 23. 
Russian hegemony and have a difficult time distinguishing the various governments in Moscow.

In this regard the new sovereign states should heed the experience of Eastern Europe. Every effort should be made to avoid the harmful collapse in trade that occurred between the Soviet Union and its former partners to the west. ${ }^{23}$ This trade collapse hurt the Eastern European countries and the Soviet Union, and there is little prospect that a surge in exports for hard currency, such as occurred in Poland, could bail out the economies of the emerging sovereign states of the former Soviet Union.

\section{Economic Reform in Ukraine}

Ukraine is the second most populous republic of the former Soviet Union. Home to 52 million people on 233,000 square miles, Ukraine resembles France in population and area. With an educated populace and a wealth of natural resources, especially agricultural and mineral, Ukraine produced just under a fifth of the net output of the Soviet Union. ${ }^{24}$ Ukraine looks and feels European. It sits across major transportation routes, including virtually all of the natural gas pipelines connecting the Soviet Union to the west. As the most important former republic next to Russia, Ukraine's participation in any confederation of states has been regarded as a key to economic success. ${ }^{25}$

Already a member of the United Nations, Ukraine has a long history as a nation, especially in the minds of Ukrainians. As a Slavic people, there is a natural connection to Russia and Belorussia, and Ukraine was part of the original formulation of the Soviet Union, an historical fact recently cited by Ukraine's president, Leonid Kravchuk, as an explanation of the difference between Ukraine's more cautious approach to independence and the Baltic states' more clamorous one. ${ }^{26}$ Of course, the

23. Williamson (1991, p. 69).

24. This conclusion is based on 1988 data from IMF and others (1991, vol. 1, p. 214).

25. " 'The union cannot survive without the Ukraine, and, I think, the Ukraine cannot survive without the union,' Gorbachev said." See David Remnick, "Prosecutors Charge 13 as Coup Leaders; Russia Enters Alliance with the Ukraine," Washington Post, August 29, 1991, p. A42.

26. Leonid Kravchuk, televised comments before Ukrainian Supreme Soviet, Kiev, Ukraine, September 3, 1991. 
Figure 2. Geography of Ukraine

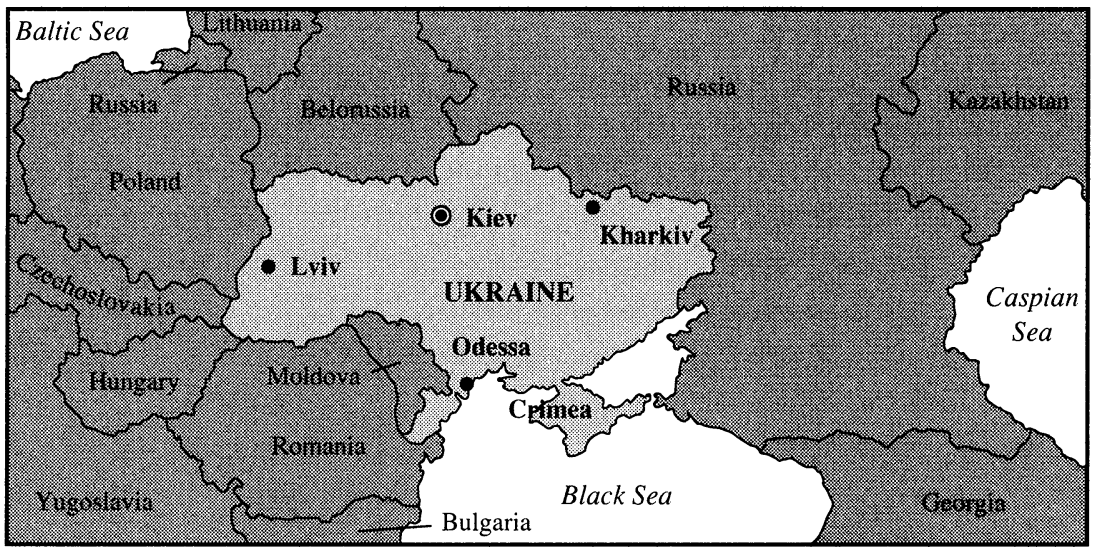

western parts of Ukraine were incorporated from Poland only at the end of the Second World War, a record reflected in the greater concentration of ethnic Ukrainians and political radicalism in Lviv (see figure 2). The eastern and southern parts of Ukraine, especially Crimea, Odessa and its oblast, and Kharkiv oblast, contain a large Russian population and were the targets of a recent, hastily withdrawn, territorial claim by the Russian Federation. ${ }^{27}$ Reportedly little more than a third of this Russian minority speaks the now politically correct Ukrainian language. ${ }^{28}$

Ukrainians and their language have long been suppressed by Moscow. This suppression predates the Soviet system and was probably worse in Czarist times..$^{29}$ Under the Soviet system, there were alternating periods of promotion and repression of Ukrainian national identity and language, with repression the dominant theme. The result has been the development of a strong sense of anti-Soviet, independent Ukrainian nationhood, especially among the intelligentsia. ${ }^{30}$

27. On Tuesday, August 27, 1991, Boris Yeltsin released a press statement raising the issue of territorial claims. Peter Maass, "Ukrainians Fear Border Disputes Could Bring Conflict with Russia," Washington Post, August 28, 1991, p. A11. (The resulting furor in Ukraine over the original mention of territorial disputes precipitated the sudden visit of a Russian delegation the next day.)

28. IMF and others (1991, vol. 1, p. 205).

29. "The state of Ukrainian language publishing is graphically portrayed by statistics on the number of books and brochures that appeared (in the Russian Empire as a whole) between 1798 and 1916 (inclusive). In that 118-year period 3,214 titles saw publication, on the average 27 titles per year for a population of approximately 20 million!' Krawchenko (1985, p. 27).

30. Krawchenko (1985, p. 253). 
Ukrainians' outrage at their oppression is often interpreted in terms of hostility toward Russia and Russians, which might imply special difficulties for ethnic Russians in Ukraine or for any future cooperation in an economic federation. The Supreme Soviet of Crimea, an autonomous region in Ukraine with a large majority of ethnic Russians, is reportedly considering declaring its own independence. However, evidence suggests that the real hostility focuses on communism, the center, and Moscow. ${ }^{31}$ In my experience, Ukrainians often describe the exploitation of Ukraine as matched or exceeded only by the exploitation of Russia beyond the center. If true, the implications for future economic cooperation are clear. Ukrainians are disposed by history and driven by economic necessity to cooperate with Russia and the other republics. However, in the minds of Ukrainians, this cooperation can proceed only between full, independent, sovereign partners. Any bow to Moscow or a reborn center will be roundly criticized in Kiev.

This tendency is evident in the attacks on President Kravchuk for his recent agreement to participate in Gorbachev's new State Council of ten. ${ }^{32}$ Ukraine is developing a large and increasingly vigorous democratic political movement. Organized in 1989, the Popular Movement of Ukraine for Restructuring (Rukh) is a consortium of democratic, anticommunist groups organized under the leadership of poet Ivan Drach. ${ }^{33}$ Strongest in western Ukraine, Rukh overcame official roadblocks to place a large minority of deputies in the first elections to the Ukrainian parliament. More recently, Narodna Rada ("people's council") has evolved to organize the opposition and launch a political campaign to gain control of the parliament. Rukh, Narodna Rada (which immediately denounced the Yannayev coup on August 19), and other new democratic opposition organizations have offered their own candidates for the first popular election to the presidency, scheduled for December 1, 1991. The political agendas of Rukh and Narodna Rada have emphasized independence from Moscow, complete and uncompromising. The popularity of their agendas has been so pervasive among Ukrainians of

31. Roman Szporluk, “Clever Ukrainians," New York Times, August 1, 1991, p. A21.

32. ". . . the opposition here called for a press conference and denounced the move as the end of our week-long 'paper independence.' For them it is impermissible that Kravchuk supported any kind of announcement that hints at the future existence of a central authority." Report by Santiago Eder on Narodna Rada press conference, Kiev, Ukraine, September 2, 1991.

33. $\operatorname{Kuzio}(1990$, p. 91). 
all ethnic persuasions that the theme was embraced in recent months by communist leaders like President Kravchuk, preempting the opposition's main issue. ${ }^{34}$ After the coup, Kravchuk again emphasized the independence theme as the first in his list of five principal positions that would govern any arrangements with a new confederation of states. With the Communist party in disarray, the democratic movement's pressure for real independence will only grow.

Ukraine will be a sowereign state, and it will take charge of its own economic reform program. Ukrainian laws have been declared supreme on Ukrainian territory, and their supremacy now looks like reality not rhetoric. Ukraine has asserted ownership of all property on its territory. Ukrainian control of its ecology is a priority that cannot be left to the center, which created Chernobyl, the symbol of exploitation. ${ }^{35}$ Ukraine is now looking to its own currency, fiscal regime, privatization program, defense conversion, and so on. As of yet, there is little concern and less interest in trying to coordinate these policies as part of a larger plan across all republics. The implications are only beginning to unfold.

\section{Currency Reform}

Almost unanimously, all economic reform plans or conversations originating in the center have assumed the need to preserve a single allunion currency and monetary policy. Eduard Shevardnadze included a single currency in his "minimalist" list of central functions that should be preserved. ${ }^{36}$ Yavlinsky in his "Grand Bargain," and Stanislav Shatalin before him, assumed the continuation of a single currency. Equally unanimously, Ukrainian leaders hold to the necessity of creating a new

34. “ 'Kravchuk is talking about independence now, but we have been talking about it for years. He is very crafty,' complained Vyacheslav Chornovil, an opposition leader and 16-year political prisoner who was chosen yesterday by the Rukh independence movement as its presidential candidate." See Peter Maass, "Crafty or Committed?" Washington Post, September 2, 1991, p. A17. This trend had been anticipated: “. . . republican leaders find it not only politically profitable but imperative to fight for their sovereignty in an attempt to abandon what appears to them to be a sinking ship." Hewett (1990, p. 166).

35. "At present the Ukraine has on paper sound environmental regulations and legislation. Unfortunately, twenty years of NEPA laws and regulations in the United States have clearly demonstrated that environmental laws and regulations alone simply do not work." ZumBrunnen (1990, p. 30).

36. Eduard Shevardnadze, seminar at Harvard University, June 7, 1991. 
Ukrainian currency and managing their own monetary policy. President Kravchuk has endorsed this goal, long advocated by Volodymyr Pylypchuk, Rukh member and chairman of the Economic Reform Commission of the Ukrainian parliament. The parliament's nearly unanimous election of Volodymyr Matvienko as chairman of the new Ukrainian State Bank, on June 20, 1991, was widely interpreted as a vote in support of establishing the hryvna as the new Ukrainian currency.

The Ukrainians' motivations are many. They recognize and fear the consequences of a ruble and a central budget out of control. ${ }^{37}$ The descriptions of the current huge central deficit, the collapse of tax collections, the forced borrowing from banks, and the printing of new money raise the specter of hyperinflation and financial collapse. If one has little confidence in Moscow, one has little hope that the ruble can be saved. There is even serious discussion in Kiev of the need to expand the Ukrainian budget deficit to avoid being left behind in the war of relative inflation across the republics.

Ukrainians report that Moscow's control of the banks has allowed practices that would cause a revolution anywhere. For example, with no checking accounts or credit cards, Ukraine is highly dependent on the regular use of the 800 million bank notes in circulation..$^{38}$ Each month the enterprises must queue up at the bank to convert their rubles on account into the paper money needed to pay their workers. However, as a normal practice, release of the cash would be delayed or denied unless the enterprise complied with some disputed directive regarding allocation of production, remission of foreign currency, transfer of accounts, and so on. No wonder that control of the currency and the banking system is repeatedly listed by Ukrainians as the first priority of economic reform. The experiment with Ukrainian coupons in the spring of 1991, designed to prevent the sale of goods to other republics for worthless rubles, ${ }^{39}$ was also viewed as a first step toward creating a new currency.

37. "Lenin is said to have declared that the best way to destroy the capitalist system is to debauch the currency. By a continuing process of inflation governments can confiscate, secretly and unobserved, an important part of the wealth of their citizens . . Lenin was certainly right." John Maynard Keynes, as quoted in Andrews (1990).

38. Estimate by Nicholas Jequier, personal communication, May 1991.

39. After President Bush's visit to Kiev on August 1, 1991, Ukrainians disagreed with his call for avoidance of trade barriers and close cooperation with Moscow: "The head of the parliamentary committee on economic reform, Volodymyr Pylypchuk, said the Ukraine was forced to take protectionist measures because of the general collapse of the 
Improved coupons were introduced in August, and the plan calls for currency-quality, reusable coupons shortly. ${ }^{40}$ Ukraine may soon confront the challenges of managing a money supply, setting exchange rates, and dealing with all the arcana of central banking. The West may need to suggest the best approaches rather than arguing the merits of the decision. ${ }^{41}$

\section{Fiscal Reform}

Ukraine plans to have complete control over taxation and state expenditures. Even before the coup, debate over the now defunct nineplus-one treaty concentrated on the role of the republics in controlling taxation and any payments to the center. After the coup, with the dissolution of the old Soviet Union, there will be little interest in leaving any significant taxing authority with the center, and the sovereign states will seek to regulate contributions to any central budget. Hence management of fiscal policy will be spread across the many governments of the sovereign states, adding another pressure to create a new currency. One key will be to develop the new institutions that can protect the monetary authorities from the probably inevitable pressure to finance state deficits by expansion of the money supply.

\section{Privatization}

In May 1991, Ukraine's parliament elected 39-year-old Volodymyr Lanovoy as the new state minister for Property and Entrepreneurship, his first position in government after spending the past year leading a team drafting reform legislation for the parliament. Nominated and supported by both Pylypchuk and Vitold Fokin, prime minister and com-

Soviet economy. He accused the central government of flooding the country with worthless rubles, forcing republics such as the Ukraine to defend themselves as best they could. . . . 'The ruble is a dead currency,' he said. 'Bush does not seem to understand that we are forced to take measures to prevent our economy collapsing completely.' " Ann Devroy and Michael Dobbs, "Bush Warns Ukraine on Independence; President Supports Gorbachev's Union Treaty in Kiev Speech,"'Washington Post, August 2, 1991, p. A1. These sentiments were anticipated: "Republics and even cities will respond to the crisis by seeking to hold onto the scarce products that they produce, increasing the fragmentation of the economy.' 'Hewett (1990, p. 166).

40. Volodymyr Pylypchuk, personal communication, August 5, 1991.

41. Williamson (1991). 
munist at the time, Lanovoy is an economist who sees himself with a broad and broadly supported mandate to develop and implement a radical program to move to a market economy. His responsibilities include privatization, development of small business, creation of an antimonopoly program, and more. Lanovoy is familiar with the ongoing experience in Eastern Europe, and he participated in a recent workshop on privatization in Gdansk. ${ }^{42}$ Senior members of his team of Ukrainian advisers attended a similar workshop in Prague in July. ${ }^{43}$ Lanovoy and his colleagues are astute and eager.

In August, before the coup, Lanovoy and his team were working on an ambitious program for massive, wide-ranging privatization of state enterprises in Ukraine. The first step was to develop a legal foundation for asserting ownership of all property on Ukrainian territory. Title to this property would rest with the newly created State Property Fund. Optimistically, this confrontation with the center was expected to require months of preparation and legal warfare, and Lanovoy was confident of ultimate success. After the coup, this legal battle was measured in hours not months; apparently the center lost by default, and Ukraine will now control all the property within its borders.

This development will accelerate the Ukrainian program for privatization, though the task ahead for Lanovoy and his colleagues is daunting. ${ }^{44}$ Much like that in Poland and other socialist countries, the Ukrainian economy is dominated by very large enterprises. As shown in figure 3 for Soviet industry, there are several thousand large state enterprises.

42. Workshop on the Social and Political Consequences of Privatization, Gdansk, Poland, April 10-12, 1991. The conference was organized by Project Liberty of Harvard University and The Gdansk Institute for Market Economics, Gdansk, Poland.

43. Privatization seminar, Central European University, Prague, Czechoslovakia, July 26-30, 1991.

44. "The problems inherent in the economic transformation that Ukraine is currently contemplating are, of course, enormous. The historical structure of the economy means that important skills and institutions of a market economy are lacking in Ukraine. Few concentrations of capital are available for commercial investment. Capital markets in debt and equity as well as the popular understanding of the role of capital are very underdeveloped. Few people have the necessary skills for assessing a business, monitoring management in a competitive market environment, or making a financial valuation. The domestic private sector is dwarfed by the state sector, which is often deliberately structured in a monopolistic manner. Additionally, there are pervasive conflicts of interest among the state bureaucrats who are often mainly interested in their own personal futures." Palmer (1991, p. 467). 
Figure 3. Size Distribution of Soviet Firms, 1988

Employees (in millions)

and enterprises (in thousands)

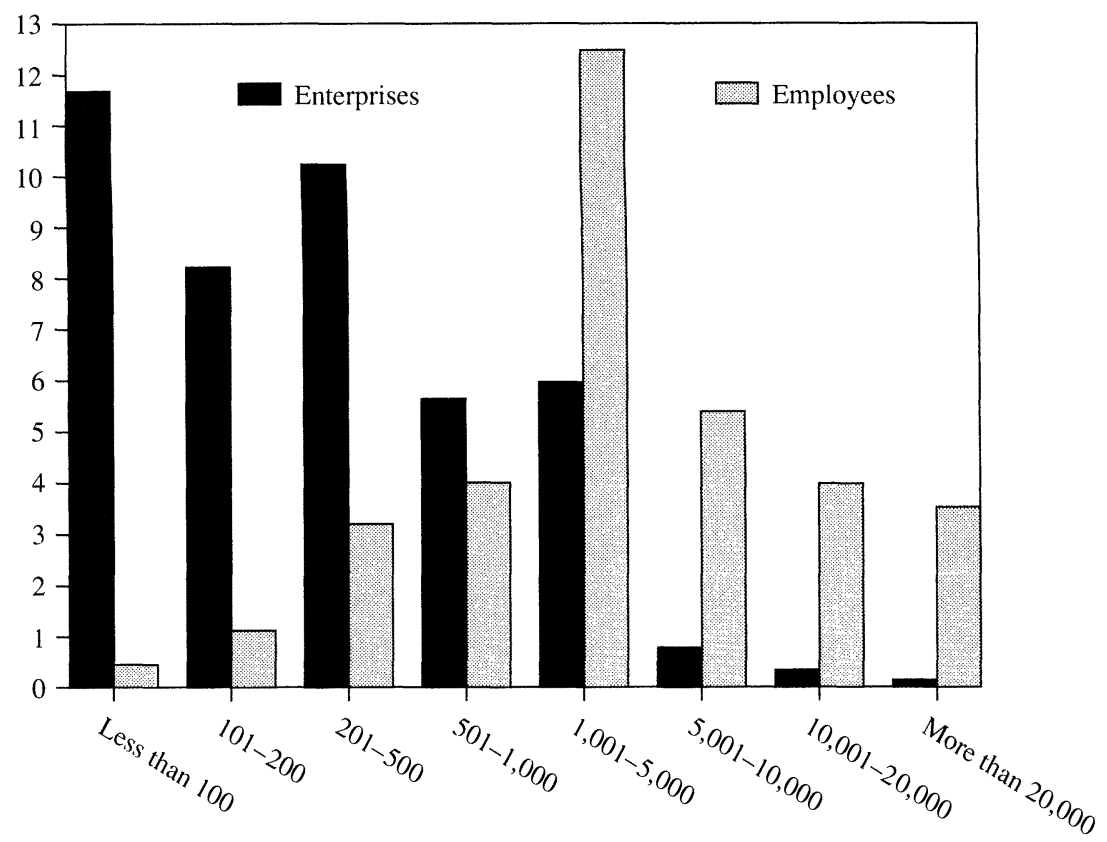

Enterprise size (by number of employees)

Source: IMF and others (1991, vol. 2, p. 37).

Although I do not have comparable data for Ukraine, the distribution would be similar. The total Ukrainian privatization program must deal with upwards of 30,000 state enterprises, including perhaps 15,000 enterprises of more than 1,000 employees, and 1,000 enterprises of more than 3,000 employees. ${ }^{45}$ There has been talk of privatizing 50 percent of these enterprises by the end of 1992 .

Considering the experience of Poland, East Germany, and the other Eastern European countries, these statistics could easily paralyze. The pressure for rapid privatization is enormous, as this is the promised cure for economic stagnation. Equally compelling is the fear that this pace is practically and politically impossible:

45. Volodymyr Lanovoy, personal communication, August 3, 1991. 
The fact that a large part of the country's capital stock may be nonviable carries with it a potential danger that a rapid exposure of the enterprises with negative value to the rigors of hard budget constraints and a competitive environment may result in a string of bankruptcies, leading to a swift fall in production and skyrocketing levels of unemployment. This, in turn, may destabilize the political situation and endanger the whole reform process. ${ }^{46}$

Perhaps János Kornai's counsel against any "vain hope" of speedy privatization, based on his distillation of Hungarian experience, gives a glimpse of the complexity of the problem. "The proportions between the private and state sectors will shift in the former's favor continually (and one hopes, as fast as possible), but there is still a lengthy period of coexistence between them ahead." 47 Lanovoy is addressing this dilemma now, but he does not look to Moscow for help.

\section{Defense Conversion}

Conversion of defense enterprises from military to civilian production is an essential requirement for improvement of the Ukrainian economy. Compared with the West, Soviet military enterprises occupy far more of the economy and dominate the better technologies. In the existing structure, the best talent and the best plants fall under the control of the defense ministries. By definition, therefore, successful economic reform must include reform through conversion of these military enterprises. Even entrepreneurs creating new enterprises will look to the existing pool of talent and technology in the defense sector.

Ukrainian leaders recognize the need to convert defense enterprises. These enterprises have already faced dramatic reductions of 30 to 50 percent in the volume of "state orders" for military goods. Nothing in their experience with central planning and central direction has prepared the defense enterprises for this new world of product and market development. Hence leaders of defense enterprises must reorient their organizations and develop new skills for a new world, and this responsibility now falls to the leadership in Ukraine. In May 1991, Viktor Antonov, then in his first days as Ukraine's state minister for the Military Complex and Conversion, made a bold claim: "I believe 100 percent of the military complex located on Ukrainian territory will come under di-

46. Frydman and Rapaczynski (1991, p. 22).

47. Kornai (1990, p. 101). 
rect Ukrainian control, starting on 1 January 1992." 48 Another answered prayer.

Reviews of past military conversion efforts in the West find virtually no examples of successful conversion in the narrow Ukrainian sense of changing an existing plant and production team working for the military market and redirecting them to produce for the civilian market. ${ }^{49}$ The problem centers on the essential culture of the military production enterprise: hierarchical organization, single-customer negotiations, cost-plus pricing, and small-batch runs. By contrast, a market economy requires decentralization, market research, value pricing, and mass production or multiple products for market niches. Organizations built for one role have floundered when confronted with the new challenge. The cultural shift is too onerous. Successful conversion has come from shrinking the old and growing the new. Human and capital resources must leave the existing enterprises and migrate to new organizations.

This message is bad news for a Ukraine encumbered with the central planning legacies of an immobile labor force and virtually no capital market. In the Ukrainian context, therefore, enterprise and government leaders must look at methods for reorganizing existing entities and directing them to operate in a market economy. In the few cases in the West where a new organization arose under the banner of the old company, the process required selective skimming of people and resources. In addition, the transformation required sustained protection of the new division to allow innovation and to insulate the new firm from the procedures, structures, and standards of the old.$^{50}$ All this requires the luxury of time and resources, neither of which is in abundant supply in Ukraine.

\section{Conclusion}

The evidence from Ukraine of the drive for true independence has parallels in each of the new sovereign states. The Baltics are gone; the other sovereign states will slowly assert control over their own economic reform plans, if only out of self-defense. The initial reaction of

48. CONVERSION'91, military conversion conference, Kiev, Ukraine, May 27-29, 1991, organized by the Project on Economic Reform in Ukraine.

49. Lynch $(1987$, p. 5$)$.

50. Lindsay (1991). 
many Western analysts has been to applaud the political revolution but to view the expanding economic chaos with dismay. For these highly interdependent economies, a little central design has appeal from afar. Managing many new currencies seems to create multiplicative problems. And the specter of Yugoslavia gives us all pause; it is in everyone's interest to avoid any expansion or spread of violence among the many ethnic groups scattered across these new states of the old Soviet Union.

However, the emerging nation cannot go back to a strong union. Western misgivings may be well founded. "But the fact is that what happens in the Soviet Union is far too important for the West to stand by and watch with no attempt to help the Soviets sift sense from nonsense." ${ }_{51}$ The West's principal task today must be to mount large-scale programs of technical assistance, on an emergency basis, to help in the sifting. And this effort must now be directed to the new sovereign states. ${ }^{52}$ Looking on the bright side, with many parallel reform experiments under way, there will be much that one state can learn from another, and the individual mistakes will be somewhat smaller and more contained. The challenge will surely provide all the challenge that one could want in new and unmapped terrains.

51. Williamson (1991, p. 85).

52. The presidium of the Ukrainian Soviet has an advisory council organized by Bohdan Hawrylyshyn of Switzerland with support from the Soros Foundation. Harvard's Project on Economic Reform in Ukraine is working with the Council of Ministers and the parliamentary Commission on Economic Reform, and the program on Strengthening Democratic Institutions has many connections in Moscow. The Hudson Institute is working closely with the Baltics. Similar initial efforts are under way elsewhere. But individually and collectively these are drops on a parched land. 